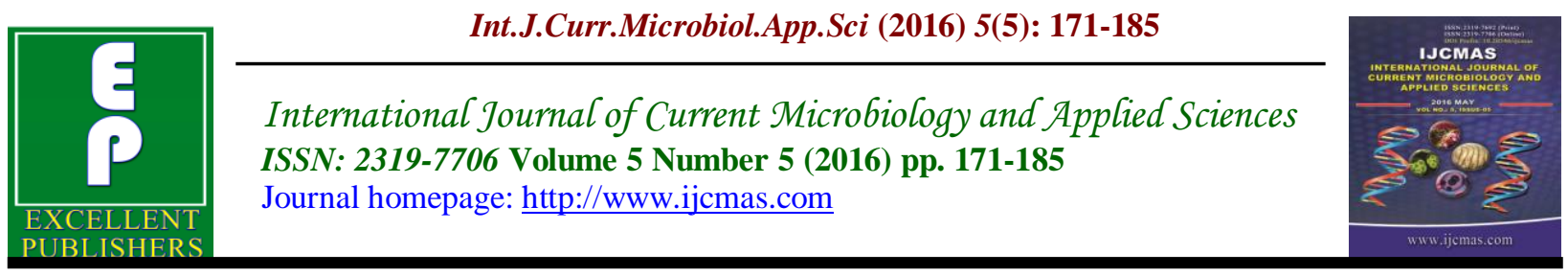

Original Research Article

http://dx.doi.org/10.20546/ijcmas.2016.505.019

\title{
Removal of Cr (VI) from Aqueous Metal Solution using Roasted China Clay
}

\author{
Shamim Ahmad ${ }^{1}$, Anwer Ali ${ }^{1}$ and Ahmad Ashfaq ${ }^{2} *$ \\ ${ }^{1}$ Department of Chemistry, D.S. College, Aligarh, Dr. B. R. Ambedkar University, \\ Agra (U.P), India \\ ${ }^{2}$ Civil Engineering Section, Faculty of Engineering \& Technology, Aligarh Muslim University, \\ Aligarh, India \\ *Corresponding author
}

Keywords

Adsorption,

Chromium,

Roasted China

Clay, FTIR,

SEM, Morphology,

Functional group.

\section{Article Info}

Accepted:

10 April 2016

Available Online:

10 May 2016
A B S T R A C T

This study was focused on the use of Roasted China Clay (RCC) as an alternative adsorbent for the removal of $\mathrm{Cr}(\mathrm{VI})$ from aqueous solution. As $\mathrm{Cr}(\mathrm{VI})$ above permissible limit is toxic for biological systems and carcinogenic for both animals and plants, therefore it is a matter of great interest to remove it from aqueous systems. Batch experiments were conducted to determine the potential of RCC as an adsorbent by studying the effect of initial metal ion concentration, contact time, adsorbent dose and $\mathrm{pH}$ of solution on adsorption of $\mathrm{Cr}$ (VI). The maximum adsorption $(81.66 \%)$ was found at $\mathrm{pH} 3$ with initial metal ion concentration 50 $\mathrm{mg} / \mathrm{L}$. Adsorption of $\mathrm{Cr}(\mathrm{VI})$ ions depends upon the initial concentration of metal ions. $0.5 \mathrm{~g}$ of RCC was able to remove $93.34 \%$ of $\mathrm{Cr}(\mathrm{VI})$ of conc. $25 \mathrm{mg} / \mathrm{L}$ and remove $69.84 \%$ of $\mathrm{Cr}(\mathrm{VI})$ of conc. $150 \mathrm{mg} / \mathrm{L}$. The value of $\mathrm{R}^{2} \approx 0.9694$ and $\mathrm{R}^{2} \approx$ 0.9329 for Freundlich and Langmuir plots respectively suggested that adsorption of Cr(VI) by RCC obey Freundlich model more appropriately than Langmuir model. Kinetic models plotted for the obtained results showed that the adsorption of $\mathrm{Cr}(\mathrm{VI})$ by RCC is of second order reaction. FTIR and SEM analysis had been carried out to study the functional group and surface morphology of the adsorbent. The adsorption capacity of Roasted China Clay was found greater than most of the clay based adsorbents reported. Kinetic studies showed that experimental data was best described by pseudo second order model.

\section{Introduction}

Chromium is an essential nutrient for plants and animal metabolism. Chromium species is mainly exists in two different oxidation states in aqueous solution. $\mathrm{Cr}$ (III) is considered as an essential trace element for the maintenance of effective glucose, lipid and protein metabolism in mammals (Kotash et al., 2000). On the other hand, $\mathrm{Cr}(\mathrm{VI})$ which is present as either dichromate
$\left(\mathrm{Cr}_{2} \mathrm{O}_{7}{ }^{2-}\right)$ in acidic environment or chromate $\left(\mathrm{CrO}_{4}{ }^{2-}\right)$ in alkaline environments can be toxic for biological systems (Shankar et al., 2005) and carcinogenic for both humans and animals (Mungasavalli et al., 2007).Therefore, the toxicity and biological activity of the Chromium not only depends on the total amount but also on its chemical form (Kot et al., 2000; Dehiram et al., 
2010). Chromium in its hexavalent form being toxic is introduced into the water bodies from different industrial processes such as tanning, electroplating, metal processing, paint manufacturing, steel fabrication and agricultural runoff (Shrivastava et al., 2008). According to USEPA the maximum permissible limits in waste water and portable water for chromium is $1.0 \mathrm{mg} / \mathrm{L}$ and $0.05 \mathrm{mg} / \mathrm{L}$ respectively (Park et al, 2005). However when accumulated above the lethal limit, it is a carcinogen particularly to lungs through inhalation. Excessive intake of chromium by humans also leads to hepatic and renal damage, capillary damage, gastrointestinal irritation and central nervous system irritation (Wan Ngah et al., 2008).The ingestion of chromium causes pain, vomiting, nausea, diarrhea and hemorrhage (Browing et al., 1969). The toxic effects of chromium on both lower and higher plants have been reported (Shanker et al., 2005). Hence in order to reduce pollution, it is essential to remove $\mathrm{Cr}(\mathrm{VI})$ ions from industrial waste water before discharging into the natural environment.

The common methods for the removal of heavy metals from waste waters are chemical precipitation, ion exchange, electro-dialysis, membrane filtration and sorption of metal oxides. These methods have certain drawbacks namely, high cost, low efficiency, generation of toxic sludge or other waste that requires disposal treatment and imply operational complexity (O'Connell et al., 2008; Dada et al., 2013).The chemical methods have proved to be expensive, less efficient and increases pollution load on the environment (Barakat, 2011). Adsorption has advantages over the other methods due to its simple design with sludge free environment involving low investment (Crini, 2005; Kurniawan et al., 2005).
In recent years, numerous low cost natural materials such as glazed tea mugs, saw dust, fruit peel of orange, rice husk (Ajmal et al, 1997;1998;2000;2003),coconut fibers (Igwe et al., 2008),palm shell (Onundi et al., 2010), potato peel (Aman et al.,2008), tea waste (Amir et al., 2008), ground nut shell (S. Idris et al., 20012), chemically modified chitosan (Dai et al., 2010), neem leaves (Parineeta et al., 2013), local landfill clay (Ghorbel-Abid et al., 2011), natural clay (Sdiri et al., 2014), chitosan coated ceramic membrane (Wanida et al., 2015), kailonite clay (Kamel et al., 2004), treated old paper (Ossman et al., 2013) and tourmaline mineral (Jiang et al., 2006) ceramic water purifiers made of Iraqi Betonite type (Bp11) (Jassim et al., 2014), powdered waste sludge (PWS), dried activated sludge biomass (Ashfaq, 2011a,b), terminaliaarjuna (Rao et al., 2014), flyash (Ashfaq, 2012), potteryglaze ( Rao et al., 2012) have been used to remove chromium and other heavy metals from water and waste waters.

\section{Materials and Methods}

\section{Preparation of Adsorbent}

In the city of Khurja, pots, toys and many other decorative articles are manufactured from ceramic powder which is a mixture of china clay, animal bone, quartz and feldspar. The moulded paste of the mixture exhibit binding property after heating. First ceramic powder is converted into a semi-solid paste to mould it to various shapes of pots and toys. After firing the paste becomes hard and porous which is known as Roasted China Clay(RCC). But during the process of Firing, some of the articles breaks or get deshaped which are thrown away as waste. This thrown away waste were collected, grinded into fine particles and sieved through 100 mesh size and used as adsorbent to remove $\mathrm{Cr}(\mathrm{VI})$ from aqueous solution. 


\section{Characterization of Adsorbent}

To observed the surface morphology of the adsorbent before and after adsorption of $\mathrm{Cr}(\mathrm{VI})$, SEM analysis was employed by using Scanning Tunneling Microscope, JEOL-JSM 6510 LV at USIF (University Sophisticated Instrumentation Facility) Aligarh Muslim University, Aligarh.

The types of binding groups present on the adsorbent (RCC) were identified by using Perkin-Elmer Fourier Transformer Spectrophotometer (FTIR) Version 10.03.08 by using $\mathrm{KBr}$ pellet technique in the wavelength range $450-4000 \mathrm{~cm}^{-1}$ at Instrumentation Lab, Department of Chemistry, AMU, Aligarh.

\section{Adsorbate Solution}

All the chemicals used in the study were of analytical grade, either from Merck Pvt. Ltd. A stock solution of $500 \mathrm{mg} / \mathrm{L}$ of $\mathrm{Cr}(\mathrm{VI})$ was prepared by dissolving required amount of potassium chromate, $\mathrm{K}_{2} \mathrm{CrO}_{4}$ in double distilled water in a $500 \mathrm{ml}$ standard flask. This stock solution was used to prepare the working solutions of desired concentrations for all experiments. $\mathrm{pH}$ values of the solutions was adjusted by adding $0.1 \mathrm{~mol} / \mathrm{L}$ $\mathrm{NaOH}$ or $0.1 \mathrm{~mol} / \mathrm{L} \mathrm{HCl}$.

The concentrations of $\mathrm{Cr}(\mathrm{VI})$ in the solution before and after adsorption were measured by using GBC-902 Atomic Absorption Spectrophotometer (AAS) at the instrumentation lab, Department of botany, AMU, Aligarh.

\section{Batch Adsorption Studies}

Batch process were conducted at room temperature $27 \pm 1^{\circ} \mathrm{C}$ to study the adsorption of $\mathrm{Cr}(\mathrm{VI})$ ions on RCC. An accurately weighed $0.5 \mathrm{gm}$ of RCC was placed in $100 \mathrm{ml}$ stoppered conical flask containing $50 \mathrm{ml}$ of $\mathrm{Cr}(\mathrm{VI})$ ions solution of $50 \mathrm{mg} / \mathrm{L}$. This solution was shaken in a rotary shaker for about 15 min and kept for 24 hours to attain equilibrium. All the operations such as effect of $\mathrm{pH}$, adsorbent dose, contact time were conducted at room temperature with $50 \mathrm{ml} \mathrm{Cr}(\mathrm{VI})$ ions solutions of $50 \mathrm{mg} / \mathrm{L}$ except during the study of effect of concentration where 25 to $200 \mathrm{mg} / \mathrm{L} \mathrm{Cr}(\mathrm{VI})$ ions concentration solutions were used. After that the mixture was filtered by using whatman filter paper No. 41. The concentration of $\mathrm{Cr}(\mathrm{VI})$ ions in filtrate was analysed by AAS.

\section{Effect of pH}

The effect of $\mathrm{pH}$ on the adsorption of $\mathrm{Cr}(\mathrm{VI})$ was studied by batch process as follows: 50 $\mathrm{ml}$ of $50 \mathrm{mg} / \mathrm{L}$ (Initial concentration) metal solution was taken in a $100 \mathrm{ml}$ conical flask. The $\mathrm{pH}$ of the solution was adjusted by adding $0.1 \mathrm{M} \mathrm{HCl}$ and $0.1 \mathrm{M} \mathrm{NaOH}$ solutions by using Systronic-09 digital $\mathrm{pH}$ meter. This solution was treated with $0.5 \mathrm{gm}$ of adsorbent and after attaining equilibrium, final concentration of $\mathrm{Cr}(\mathrm{VI})$ in the solution was determined by AAS.

\section{Effect of Contact Time}

A series of $100 \mathrm{ml}$ conical flasks, each having $0.5 \mathrm{~g}$ adsorbent and $50 \mathrm{ml}$ solution of $50 \mathrm{mg} / \mathrm{L} \mathrm{Cr}(\mathrm{VI})$ concentration were shaken in a rotary shaker at predetermined intervals. The solution of the specified flask was taken out and filtered. The concentration of $\mathrm{Cr}(\mathrm{VI})$ in the filtrate was determined by AAS.

\section{Effect of Adsorbent Dose}

A series of $100 \mathrm{ml}$ conical flasks, each containing $50 \mathrm{ml}$ solution of $50 \mathrm{mg} / \mathrm{L} \mathrm{Cr}(\mathrm{VI})$ concentration were treated with varying amount adsorbent $(0.1-1.0 \mathrm{~g})$ and shaken in 
a rotary shaker at predetermined intervals. The solution of the specified flask was taken out and filtered. The concentration of $\mathrm{Cr}(\mathrm{VI})$ in the filtrate was determined by AAS.

\section{Effect of Concentration}

A series of $100 \mathrm{ml}$ conical flasks, having 0.5 $\mathrm{g}$ of adsorbent and $50 \mathrm{ml}$ solution each of varying concentration from $10-200 \mathrm{mg} / \mathrm{L}$ $\mathrm{Cr}(\mathrm{VI})$ concentration were shaken in a rotary shaker, at pre-determined intervals. The solution of the specified flask was taken out and filtered. The concentration of $\mathrm{Cr}(\mathrm{VI})$ in the filtrate was determined by AAS.

The removal percentage ( $\mathrm{R} \%$ ) of metal ions and Adsorption capacity or amount of $\mathrm{Cr}(\mathrm{VI})$ adsorbed per unit mass of adsorbent $\left(\mathrm{q}_{\mathrm{e}}\right)$ were calculated for each run by the following expression-

$$
\begin{aligned}
& \mathrm{R} \%=\frac{(C i-C e)}{C i} \times 100 \\
& \mathrm{q}_{\mathrm{e}}=\frac{(C i-C e)}{m} \times \mathrm{V}
\end{aligned}
$$

where,

$\mathrm{C}_{\mathrm{i}}=$ Initial concentration of metal ions in the solution

$\mathrm{C}_{\mathrm{e}}=$ Final concentration of metal ions in the solution

$\mathrm{V}=$ Volume of the solution $(\mathrm{L})$

$\mathrm{m}=$ Mass of the adsorbent $(\mathrm{gm})$

\section{Adsorption Isotherms}

Adsorption isotherm curve is an invaluable curve describing the phenomena governing the retention (or release) or mobility of the adsorbent from the aqueous phase to a solid phase at constant temperature and $\mathrm{pH}$ (Allen et al., 2004; Limousin et al., 2007; Foo et al., 2010). In order to model the adsorption behaviour of $\mathrm{Cr}(\mathrm{VI})$ ions on RCC, Langmuir and Freundlich adsorption isotherm were studied. The adsorption of $\mathrm{Cr}(\mathrm{VI})$ ion concentration ranging from $25 \mathrm{mg} / \mathrm{L}$ to 200 $\mathrm{mg} / \mathrm{L}$ were studied and the data obtained was analyzed with both the Langmuir and Freundlich adsorption isotherm equations.

\section{Langmuir Isotherm}

One of the most widely used model for describing heavy metals sorption is the Langmuir model. Langmuir relates the coverage of molecules on a solid surface to concentration of a medium above the solid surface at a fixed temperature. It is expressed as-

$\frac{1}{\mathrm{qe}}=1 / \mathrm{bq}_{\mathrm{m}}+1 / \mathrm{q}_{\mathrm{m}} \times 1 / \mathrm{C}_{\mathrm{e}}$

where,

$\mathrm{q}_{\mathrm{e}}$ is the amount of $\mathrm{Cr}(\mathrm{VI})$ adsorbed per unit weight of the adsorbent $(\mathrm{mg} / \mathrm{g})$ at equilibrium,

$\mathrm{C}_{\mathrm{e}}$ is the equilibrium concentration $(\mathrm{mg} / \mathrm{L})$,

$\mathrm{b}$ and $\mathrm{q}_{\mathrm{m}}$ are Langmuir constant related to the energy of adsorption and monolayer adsorption capacity of adsorbent (mg/g) respectively.

The linear plot of $1 / \mathrm{q}_{\mathrm{e}}$ vs $1 / \mathrm{C}_{\mathrm{e}}$ shows that adsorption of $\mathrm{Cr}(\mathrm{VI})$ follows the Langmuir model. The values of $\mathrm{q}_{\mathrm{m}}$ and $\mathrm{b}$ were be calculated from the intercept and slope of the plots (Langmuir, 1918). The coefficient $\mathrm{b}$ in Langmuir equation is a measure of the stability of the complex formed between metal ions and adsorbent under specified experimental conditions (Rao et al., 2007; Ayranci et al., 2005). 


\section{Freundlich Isotherm}

Freundlich isotherm is an empirical equation which was applied for adsorption of $\mathrm{Cr}(\mathrm{VI})$ and is represented as-

$\log q_{e}=\quad \log K_{f}+1 / n \log C_{e}$

where,

$\mathrm{C}_{\mathrm{e}}$ is the equilibrium concentration $(\mathrm{mg} / \mathrm{L}$ ) $\mathrm{q}_{\mathrm{e}} \mathrm{is}$ the amount of metal ions adsorbed per unit weight of the adsorbent ( $\mathrm{mg} / \mathrm{g})$.

$\mathrm{K}_{\mathrm{f}}$ and $\mathrm{n}$ are the Freundlich constant designating adsorption capacity and adsorption intensity respectively. The linear plot of $\log \mathrm{q}_{\mathrm{e}} \mathrm{vs} \log \mathrm{C}_{\mathrm{e}}$ show that the adsorption followed Freundlich model. The values of $K_{f}$ and $n$ were calculated from the intercepts and slop of the plots (Fruendlich, 1906).

\section{Adsorption Kinetics}

In order to investigate the Adsorption kinetics, the Lagergren first order (Lagergren, 1898), pseudo first-order (O'Shannessy et al., 1996) and pseudo second order kinetics models (Singh et al., 1988; Ho and Mckay, 1999) were applied. The pseudo second order model may be represented the data more appropriately when the value of correlation coefficient is greater than $0.99\left(R^{2}>0.99\right)$.

The pseudo first-order kinetic equation of Lagergren is represented as:

$\mathrm{dq}_{\mathrm{t}} / \mathrm{dt}=\mathrm{k}_{1}\left(\mathrm{q}_{\mathrm{e}}-\mathrm{q}_{\mathrm{t}}\right)$

The above equation can be integrated to yield a linearized form as

$\log \left(\mathrm{q}_{\mathrm{e}}-\mathrm{q}_{\mathrm{t}}\right)=\log \mathrm{q}_{\mathrm{e}}-\mathrm{k}_{1} \mathrm{t} / 2.303$

where, $\mathrm{k}_{1}=$ Lagergren rate constant for adsorption $\left(\min ^{-1}\right)$,

$\mathrm{q}_{\mathrm{e}}=$ Amount of metal adsorbed at equilibrium $\left(\mathrm{mg} \mathrm{g}^{-1}\right)$

$\mathrm{q}_{\mathrm{t}}=$ Amount of metal adsorbed $\left(\mathrm{mg} \mathrm{g}^{-1}\right)$ at any time $t$.

Time, $\mathrm{t}$ was plotted against $\log \left(\mathrm{q}_{\mathrm{e}}-\mathrm{q}_{\mathrm{t}}\right)$ and the values of $\mathrm{k}_{1}$ and $\mathrm{q}_{\mathrm{e}}$ was determined from the slope and intercept of lines of the plot.

The equation of pseudo second order model is:

$\mathrm{dq}_{\mathrm{t}} / \mathrm{dt}=\mathrm{k}_{2}\left(\mathrm{q}_{\mathrm{e}}-\mathrm{q}_{\mathrm{t}}\right)^{2}$

Integration and rearrangement of equation above yielded the following equation

$\mathrm{t} / \mathrm{q}_{\mathrm{t}}=1 / \mathrm{k}_{2} \mathrm{q}_{\mathrm{e}}^{2}+1 / \mathrm{q}_{\mathrm{e}} \mathrm{t}$

where,

$\mathrm{k}_{2}=$ Equilibrium rate constant of second order kinetics model $\left(\mathrm{g} \mathrm{mg}^{-1} \mathrm{~min}^{-1}\right)$,

$\mathrm{q}_{\mathrm{e}}=$ Equilibrium capacity

$\mathrm{q}_{\mathrm{t}}=$ Adsorption capacity at any time $\mathrm{t}$.

The time $t$, was plotted against $t / q_{t}$ and the values of $\mathrm{k}_{2}$ and $\mathrm{q}_{\mathrm{e}}$ was determined from the slope and intercepts of lines of the plot.

\section{Results and Discussion}

\section{Characterization of Adsorbent}

The SEM images of RCC before and after adsorption shown in Fig. 1 and 2 shows that surface of RCC is irregular and rough with almost non compact structure which means that it has considerable number of pores of different shapes and sizes, where appropriate 
conditions exists for $\mathrm{Cr}(\mathrm{VI})$ ions to be trapped and adsorbed in these pores. The bright spots in the images before adsorption show the presence of tiny holes on the surface of RCC. After treatment with metal ions, the bright spots become dark grey and black which reveal that the adsorption of $\mathrm{Cr}(\mathrm{VI})$ has occurred on the surface of RCC by means of physisorption (Sudha et al., 2007; Arivoli et al., 2007; Weber et al., 1967). The SEM images also illustrates that the adsorbent surface before adsorption seems to be less denser while after adsorption it becomes denser showing the adherence of $\mathrm{Cr}(\mathrm{VI})$ ions on the surface. Hence, adsorptive characteristics of RCC are expected to be highly effective.

\section{SEM Images}

\section{FTIR Images}

The types and structure of binding groups present on the surface of RCC were identified in the wavelength range 450-4000 $\mathrm{cm}^{-1}$. The FTIR spectra of RCC recorded before and after adsorption are shown in Fig. 3 and 4. The FTIR spectrum showed a characteristic broad peak at $3441.81 \mathrm{~cm}^{-1}$ due to the presence of hydrogen bonded $\mathrm{OH}$ group (Rao et al., 2011), while small peak at $2925.76 \mathrm{~cm}^{-1}$ indicates the presence of C-H stretched bond in alkanes. The peaks between 900 and $1100 \mathrm{~cm}^{-1}$ might be due to the presence of metal oxides (Coates, 2000) as metal oxides generally give absorption band below $1000 \mathrm{~cm}^{-1}$ arising from interatomic vibration (wang et al., 2013; Anandan et al., 2011). The peaks between 500 and $800 \mathrm{~cm}^{-1}$ indicates the presence of $\mathrm{C}-\mathrm{X}$ bonds $(\mathrm{X}=$ Halogen). When FTIR spectra of untreated RCC is compared with $\mathrm{Cr}(\mathrm{VI})$ treated RCC the shifting of bands towards lower and higher frequencies was observed. Shifting of band from 3441 to $3438 \mathrm{~cm}^{-1}$ indicates the interaction of $\mathrm{Cr}(\mathrm{VI})$ ions with $-\mathrm{OH}$ group. All the changes in the spectra of treated RCC is due to the metal bonding process on the surface of RCC.

\section{Batch Studies}

\section{Effect of pH of Metal Ions Solution of Adsorption}

The $\mathrm{pH}$ of the solution is one of the important controlling parameter in the adsorption process. The solution of $\mathrm{Cr}(\mathrm{VI})$ metal ion of concentration $50 \mathrm{mg} / \mathrm{L}$ was treated with $0.5 \mathrm{gm}$ of adsorbent at various $\mathrm{pH}$ ranging 1 to 14 . The percentage removal of $\mathrm{Cr}(\mathrm{VI})$ at various $\mathrm{pH}$ values is shown in fig. 5. It has been observed that the percent removal of metal ion decrease as $\mathrm{pH}$ value of the solution increase. Hence RCC show higher adsorption at $\mathrm{pH} 3(81.66 \%)$. At a higher $\mathrm{pH}, \mathrm{Cr}(\mathrm{VI})$ ion gets precipitated as their hydroxides which decreases the rate of adsorption and subsequently the percent removal of metal ions (Pagnonelli et al., 2003; Lugolugo et al., 2009).

\section{Effect of Concentration of Metal Ion on Adsorption}

The effect of $\mathrm{Cr}(\mathrm{VI})$ concentration in the solution for five different concentrations ( $25,50,100,150$ and $200 \mathrm{mg} / \mathrm{L}$ ) is shown in fig.6. It has been observed that theadsorption capacity of $\mathrm{Cr}(\mathrm{VI})$ increases from 2.33 $\mathrm{mg} / \mathrm{gm}$ to $14.18 \mathrm{mg} / \mathrm{gm}$ whereas the adsorption percentage decreases with the increase in concentration of metal ion on solution. This was due to the fact that empty adsorbent sites adsorbed $\mathrm{Cr}(\mathrm{VI})$ ions rapidly at lower concentration but at higher concentration adsorption of $\mathrm{Cr}(\mathrm{VI})$ ions occurred by diffusion (slower step) into the inner sites of the adsorbent. The maximum adsorption observed at $25 \mathrm{mg} / \mathrm{L}$ (93.34\%) and minimum adsorption observed at 150 $\mathrm{mg} / \mathrm{L}(69.84 \%)$. 


\section{Effect of Contact Time}

Adsorption of metal on adsorbent used increases with increasing contact time. The $\mathrm{Cr}(\mathrm{VI})$ uptake versus time curve in fig.7 shows that equilibrium is attained in $20 \mathrm{~min}$, where maximum adsorption percentage was $80.34 \%$. The adsorption percentage of metal versus time is single and continuous line leading to saturation, suggesting a monolayer adsorption on the surface of adsorbent. The equilibrium time of 20 minutes investigated in the present work was much shorter than other adsorbents reported earlier for $\mathrm{Cr}(\mathrm{VI})$ adsorption.

\section{Effect of Adsorbent Dose}

The adsorbent dose is an important parameter in adsorption studies because it determines the capacity of adsorbent for a given initial concentration of metal ion in the solution. The Adsorption percentage of $\mathrm{Cr}(\mathrm{VI})$ at different doses of adsorbent is shown in fig. 8. It was observed that increasing the adsorbent dose increased the percentage removal of $\mathrm{Cr}(\mathrm{VI})$ upto $96.66 \%$. The adsorption percentage of $\mathrm{Cr}(\mathrm{VI})$ increases with the increase of adsorbent dose, due to increase in surface area of adsorbent leading to more adsorption sites.

Fig.1 SEM Image of RCC before adsorption

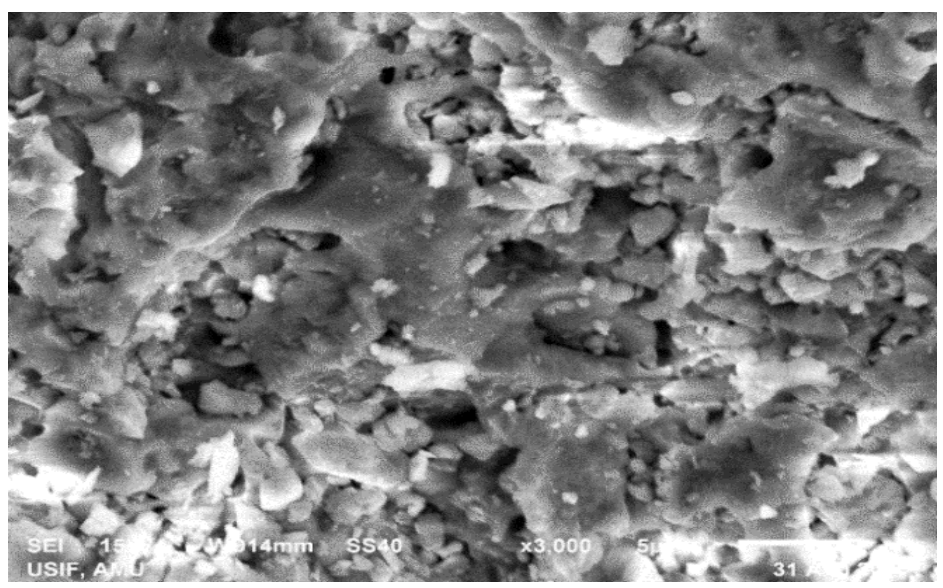

Fig.2 SEM Image of RCC after Adsorption

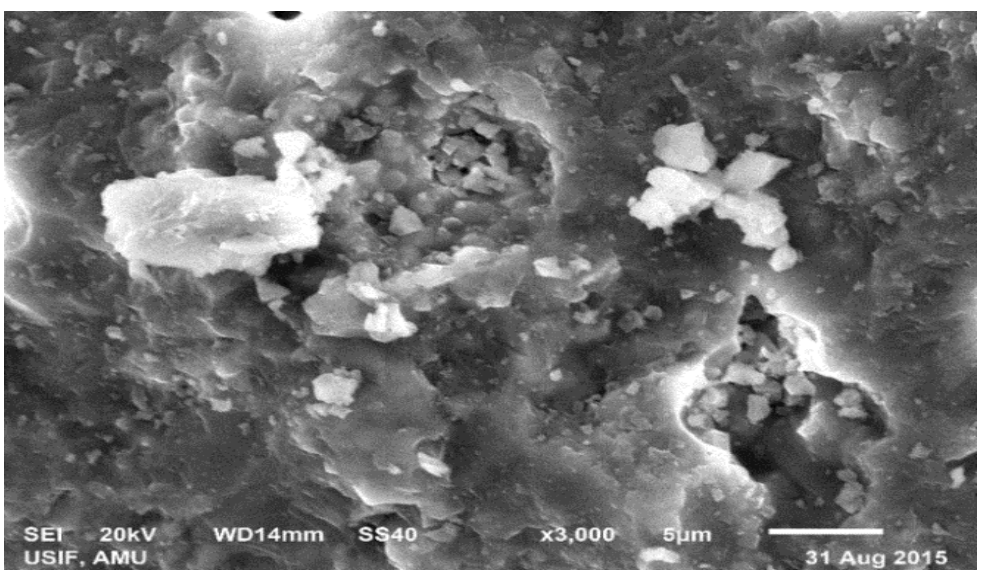



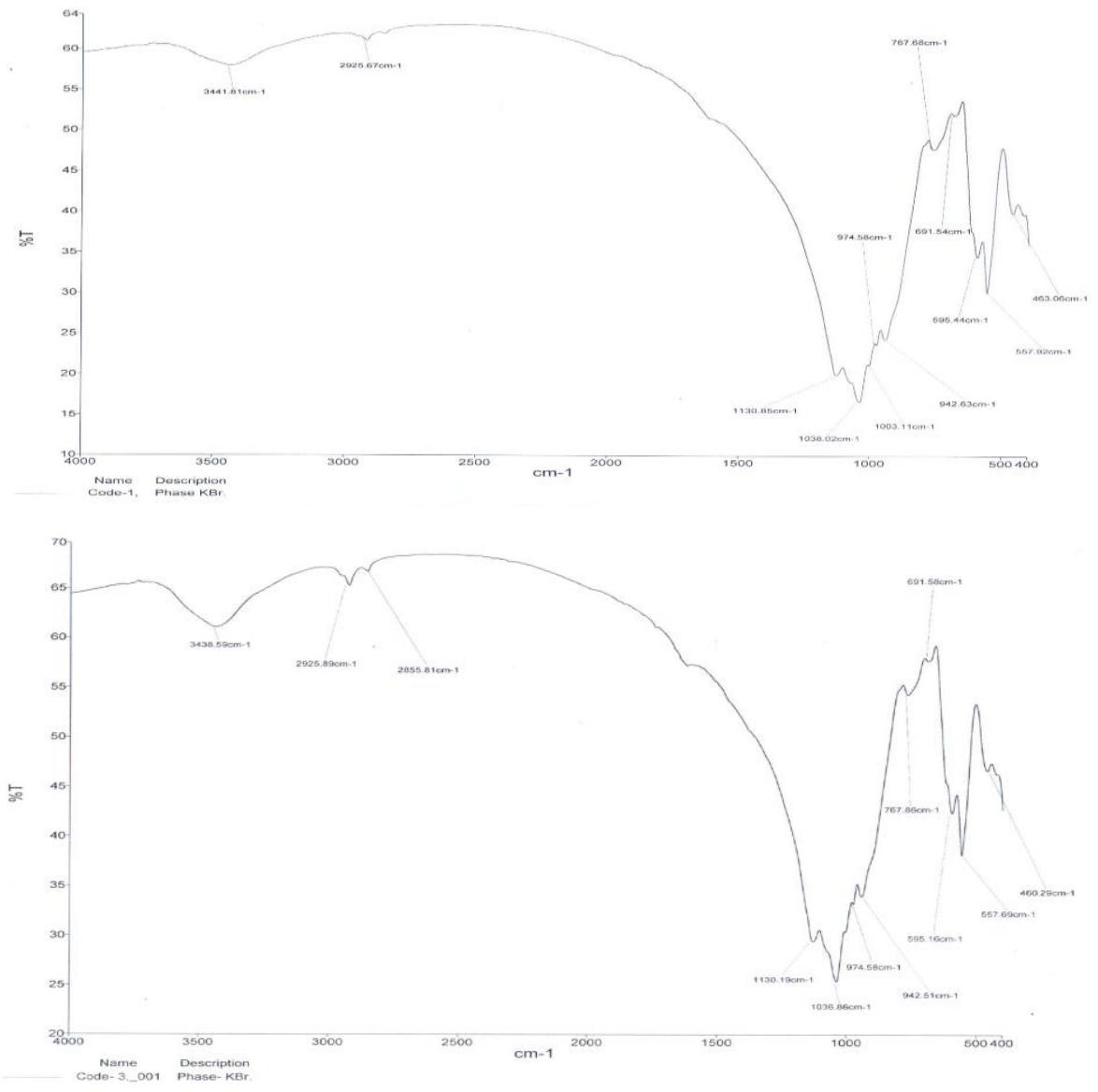

Fig.5 Effect of $\mathrm{pH}$ on Adsorption of $\mathrm{Cr}(\mathrm{VI})$

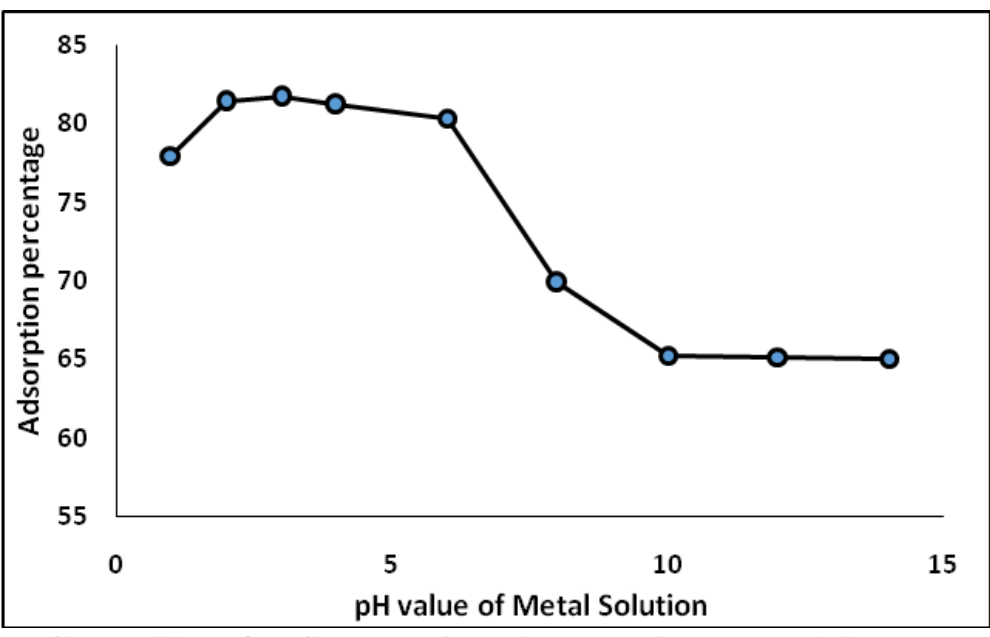

Conc.: $50 \mathrm{mg} / \mathrm{L}$; Contact Time: 2 hours; Ads. dose: 0.5gm 
Fig.6 Effect of Concentration of $\mathrm{Cr}(\mathrm{VI})$ on its Adsorption

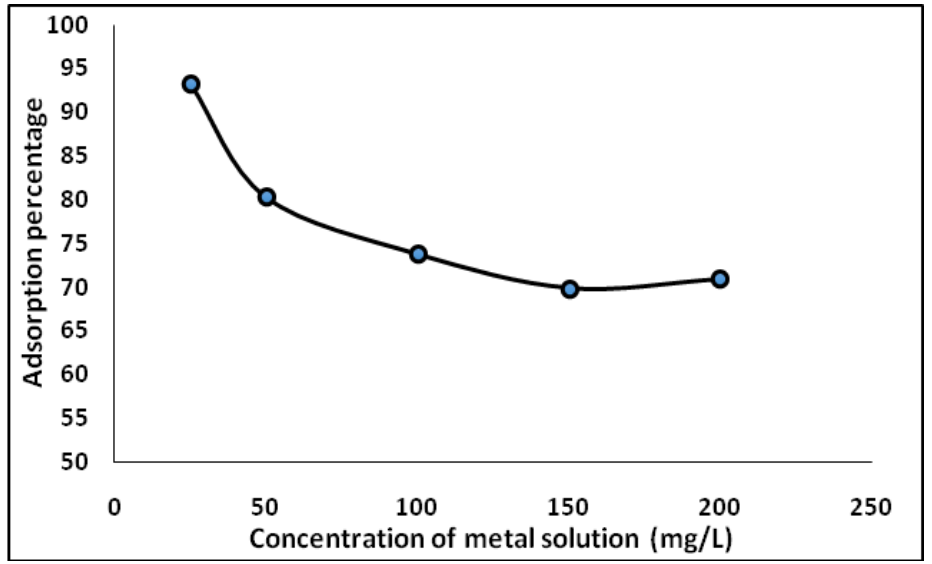

Fig.7 Effect of Contact Time of Adsorption of $\mathrm{Cr}(\mathrm{VI})$

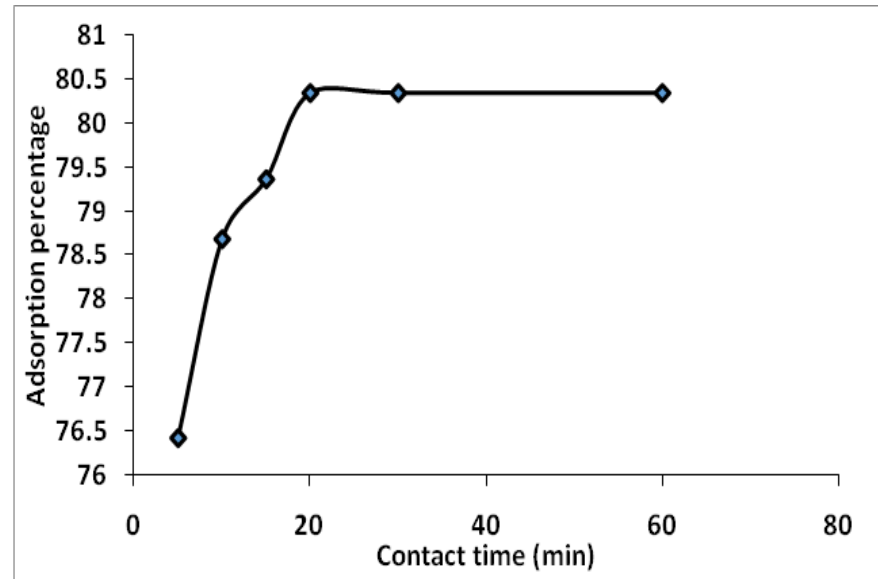

Initial conc. 50 mg/L; Ads. Dose: 0.5gm; pH: 3

Fig.8 Effect of Adsorbent Dose on Adsorption of Cr(VI)

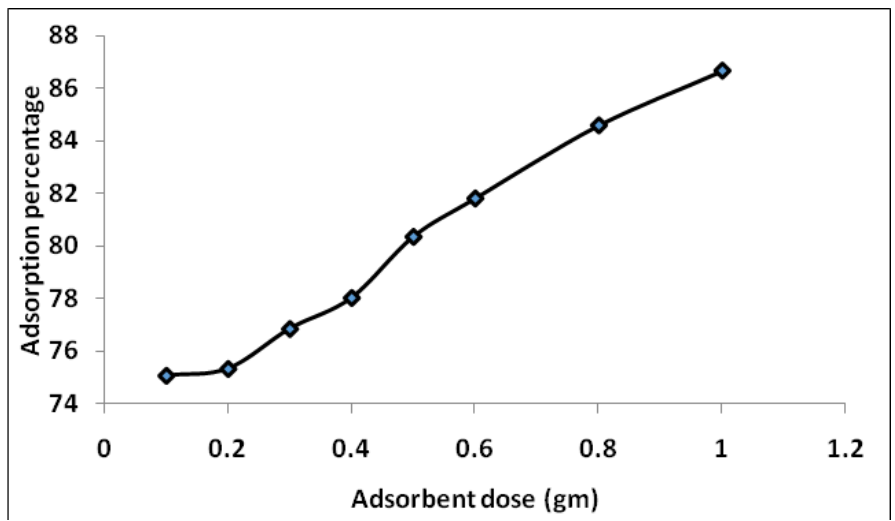

Initial concentration: 50 mg/L;Contact Time: 24 hours; $\mathbf{p H : ~} 3$ 
Fig.9 Langmuir Adsorption Isotherm Plot for Adsorption on RCC

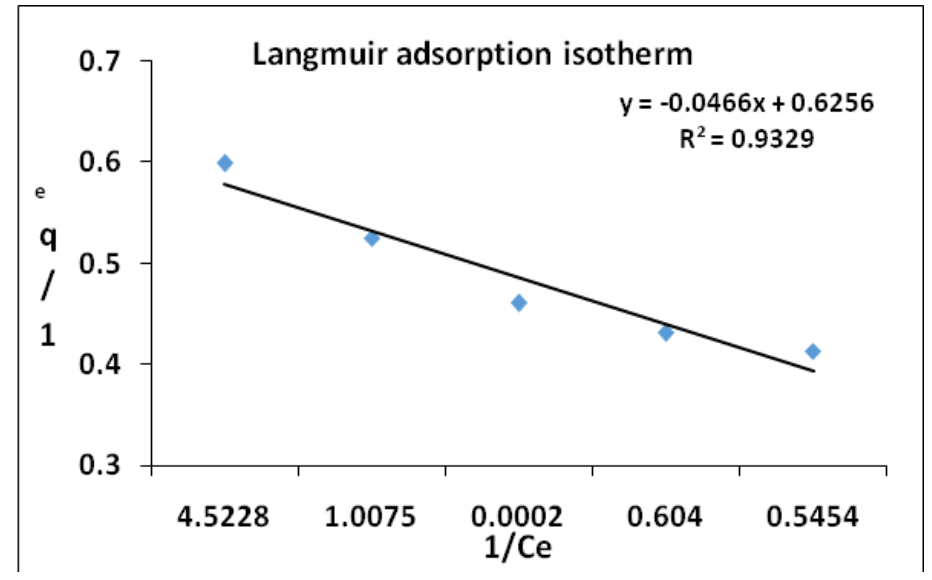

Fig.10 Freundlich Adsorption Isotherm Plot for Adsorption on RCC

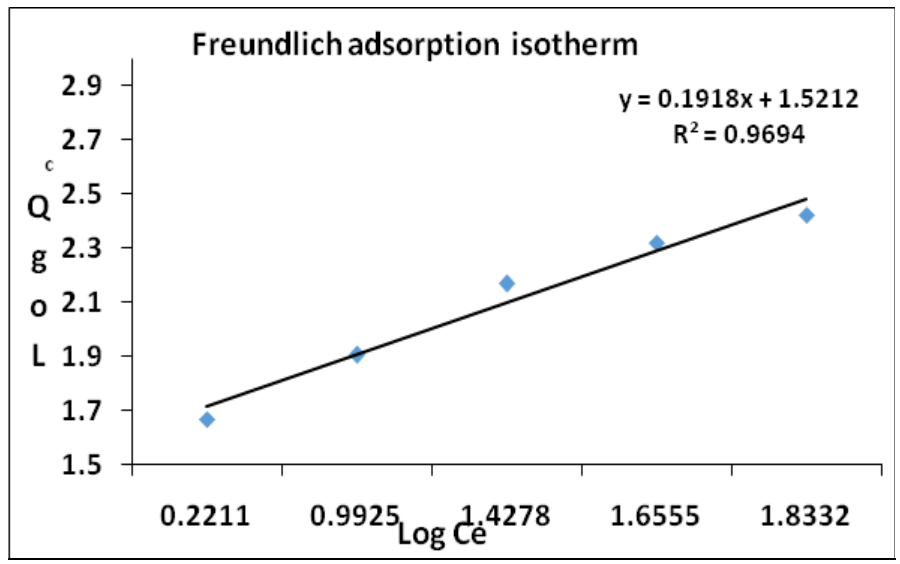

Fig.11 Pseudo First Order Plot for the Adsorption of $\mathrm{Cr}(\mathrm{VI})$ on RCC

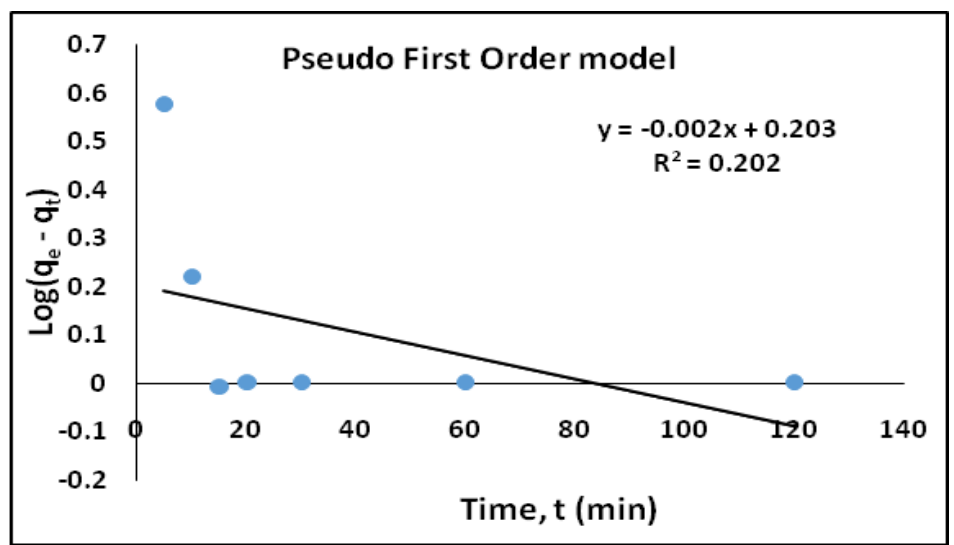


Fig.12 Pseudo Second Order Plot for Adsorption Cr(VI) on RCC

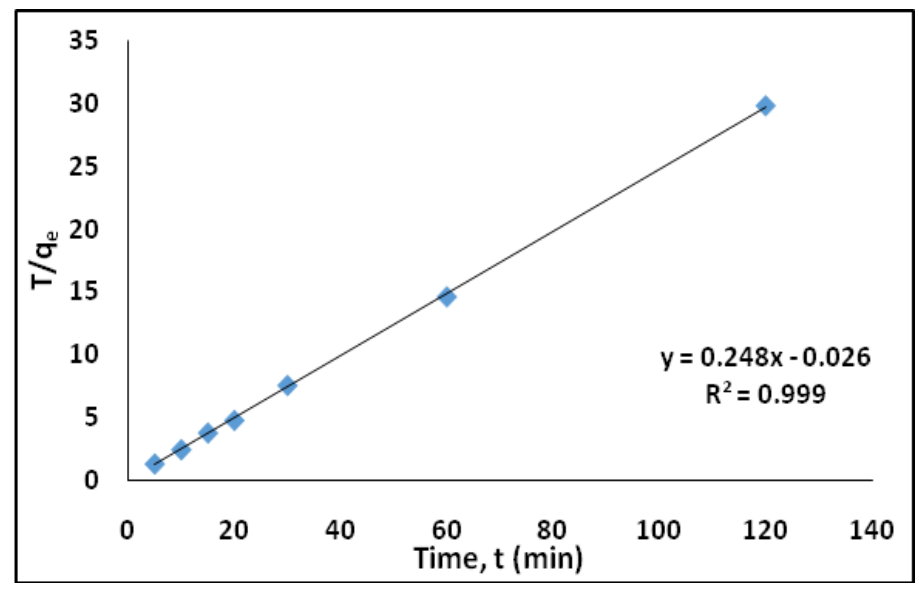

\section{Adsorption Isotherm}

Adsorption isotherm curve is an invaluable describing the phenomena governing the retention (or release) or mobility of the $\mathrm{Cr}(\mathrm{VI})$ ions from the aqueous phase to a solid phase at constant temperature and $\mathrm{pH}$ (Allen et al., 2004; Limousin et al., 2007; foo et al., 2010). The Langmuir and Freundlich isotherms were used to fit the experimental data of the adsorption of $\mathrm{Cr}(\mathrm{VI})$ at $27{ }^{\circ} \mathrm{C}$. In order to evaluate the fitness of the experimental data on Langmuir model, $1 / \mathrm{q}_{\mathrm{e}}$ were plotted against $1 / \mathrm{C}_{\mathrm{e}}$ as shown in Fig. 9 and on Freundlich model, $\log \mathrm{q}_{\mathrm{e}}$ were plotted against $\log \mathrm{C}_{\mathrm{e}}$ as shown in Fig. 10 respectively. The linearity of the graph and values of the correlation coefficient $\left(\mathrm{R}^{2}\right)$ showed that the experimental data were more appropriately fitted on Freundlich model. Moreover the values of the correlation coefficients suggests that adsorption of $\mathrm{Cr}(\mathrm{VI})$ ions on RCC occurs by the formation of homogeneous monolayer followed by multilayer formation.

\section{Adsorption Kinetics}

To find out the validity of the obtained experimental data on Pseudo first and second order equation, graph of $\log \left(\mathrm{q}_{\mathrm{e}}-\mathrm{q}_{\mathrm{t}}\right)$ vs time, $\mathrm{t}$ and $\mathrm{t} / \mathrm{q}_{\mathrm{t}} \mathrm{vs}$ time, $\mathrm{t}$ was plotted as shown in Fig. 11 and Fig.12. A straight line was obtained and the value of correlation coefficient $\left(\mathrm{R}^{2} \approx 0.9998\right)$ as observed in Fig. illustrate that adsorbate-adsorbent system obeyed Pseudo second order model. Furthermore, the applicability of Pseudo second order model confirmed that $\mathrm{Cr}(\mathrm{VI})$ ions during adsorption form multilayer on the surface of particles of RCC.

In conclusion, the present study was to evaluate the RCC as possible potential adsorbent for removal of $\mathrm{Cr}(\mathrm{VI})$ from synthetic wastewater by batch process. It was found that the adsorption of $\mathrm{Cr}(\mathrm{VI})$ ions by RCC was $\mathrm{pH}$ dependent and the optimum $\mathrm{pH}$ for the maximum removal $(81.66 \%)$ of $\mathrm{Cr}(\mathrm{VI})$ from aqueous solution was 3 and obeying Freundlich model more appropriately than Langmuir model. From the study of kinetic models plotted for the obtained results showed that the adsorption of $\mathrm{Cr}(\mathrm{VI})$ by $\mathrm{RCC}$ is of second order reaction. It is also important to remark that the Roasted China Clay is economic and easily available material and after treatment with heavy metals a very low amount of sludge is produced which may be disposed off without causing any harm to the environment. The results showed that the Roasted China Clay has been found very 
effective and environment friendly adsorbent which can remove sufficient amount of $\mathrm{Cr}(\mathrm{VI})$ from aqueous solution in very small period of contact time (in this case 20 minutes). Hence, RCC can be utilized in wastewater treatment containing $\mathrm{Cr}$ (VI) as pollutants without any chemical treatment.

\section{Acknowledgement}

The authors gratefully acknowledge Head, Department of Chemistry, D.S. College, Aligarh for providing research facilities. The support of the Principal, Civil Engineering Section, Faculty of Engineering and Technology, AMU, Aligarh is also acknowledged. The Instrumentation Lab facility provided by Department of Chemistry, AMU, Aligarh is greatly appreciated.

\section{References}

Abid, I.G., Ayadi, M.T. 2015. Competitive adsorption of heavy metals on local landfill clay. Arabian J. Chem., 8: 2531.

Ahmad Ashfaq, 2011a. Removal of $\mathrm{Cr}(\mathrm{III})$ by biosorption onto powdered waste sludge (PWS): Effects of operating conditions. Int. J. Ecol. Environ. Conservation. 17(3): 593-596.

Ahmad Ashfaq, 2011b. Cd(II) removal from aqueous solution by dried activated sludge biomass. Int. J. Pollution Res., 30(3): 357-360.

Ahmad Ashfaq, 2012. Evaluation of biosorption characteristics in mixed heavy metal solution by flyash. International Conference on Interface between Chemistry and Environment. Deptt. Of Chemistry, Ramjas College, University of Delhi, India. $13^{\text {th }}$ and $14^{\text {th }}$ march 2012.

Ajmal, M., Khan, A.H., Shamim Ahmad,
Anees, A. 1998. Role of saw dust in the removal of $\mathrm{Cu}(\mathrm{II})$ from industrial waste water. Water Res., 32(10): 30853091.

Ajmal, M., Khan, A.U., Nomani, A.A., Shamim Ahmad. 1997. Heavy metals leaching from glazed surfaces of tea mugs. Sci. Total Environ. Netherlands, 207(1): 49-54.

Ajmal, M., Rao, R.A.K., Ahmad, Ahmad, R. 2000. Adsorption studies on Citrus Reticulate (Fruit peel of orange): Removaland recovery of $\mathrm{Ni}(\mathrm{II})$ from electroplating waste water. $J$. Hazardous Material, 79: 117-131.

Ajmal, M., Rao, R.A.K., Anwar, J.A., Ahmad, R. 2003. Adsorption studies on rice husk: Removal and recovery of $\mathrm{Cu}(\mathrm{II})$ from waste water. Biores. Technol., 86: 147-149.

Allen, S.J., Mckay, G., Porter, J.F. 2004. Adsorption isotherm models for basic dye adsorption by peat in single and binary system. J. colloid Interface Sci., 280: 322-333.

Aman, T., Kazi, A.A., Sabri, M.U., Bana, Q. 2008. Potato peels as solid waste for the removal of heavy metal $\mathrm{Cu}(\mathrm{II})$ from waste/industrial effluent. Colloids and Surfaces B: Biointerfaces, 63(1): 116-121.

Amir, H.M., Dariush, N., Forugh, V., Shahrolch, N. 2005. Tea waste as an adsorbent for heavy metals removal from industrial wastewaters. J. Applied Sci., 2(1): 372-375.

Anandan, K., Rajendran, V. 2011. Morphological and size effects of $\mathrm{NiO}$ nanoparticles via solvothermal process and their optical properties. Matter Sci. Semicond. Process, 14: 43-47.

Arivoli, S. 2007. Kinetics and thermodynamics studies on the adsorption of some metal ions and dyes onto low cost activated carbons, Ph.D., Thesis, Gandhigram Rural 
University, Gandhigram.

Ayranci, A., Duman, O. 2005. Adsorption behaviours of some phenolic compounds onto high specific area of activated carbon cloth. J. Hazardous Matter, 124: 125-132.

Barakat, M.A. 2011. New trends in removing heavy metals from industrial wastewater. Arabian J. Chem., 4: 361377.

Browing, E. 1969. Toxicity of industrial metal, $2^{\text {nd }}$ edition, Pub. Butterworth, London, Chapter- 12.

Coates, J.P. 2000. Interpretation of infrared spectra in a practical approach by John Coates in Encyclopedia of Analytical Chemistry (Meyer R.A) [M]. John Waley and Sons Ltd. Chichester. U.K., 10815-10837.

Crini, G. 2005. Recent developments in polysaccharide-based materials used as adsorbent in Wastewater treatment. Progress in Polymer Sci., 30: 38-70.

Dada, A.O., Ojediran, J.O., Olalekan, A.P. 2013. Sorption of $\mathrm{Pb}^{2+}$ from aqueous solution onto modified Rice Husk: Isotherm studies. J. Advances in Physical Chem., 1-6.

Dai, J., Ren, F.L., Tao, C.Y. 2012. Adsorption of $\mathrm{Cr}(\mathrm{VI})$ and speciation of $\mathrm{Cr}(\mathrm{VI})$ and $\mathrm{Cr}(\mathrm{III})$ in aqueous solutions using chemically modified chitosan. Int. J. Environ. Res. public health, 9(5): 1757-1770.

Dehirham, C., Mustafa, T.S. 2010. Speciation of $\mathrm{Mn}(\mathrm{II})$ and $\mathrm{Mn}(\mathrm{VII})$ samples by co-precipitation-atomic absorption spectrometry combination. J. Hazardous Matter, 173: 773-777.

Doughee, P., Yeong-Sang, Y., Jong Moon, P. 2005. Studies on hexavalent chromium Biosorptionby chemically treated Biomass of ecklonia. Sp. Chemosphere, 60(10): 1356-1364.

Foo, K.Y., Hameed, B.H. 2010. Insight into the modelling of adsorption isotherms.
Chemical Engg. J., 156: 2-10.

Freundlich, H.M.F.1906. Uber die sorption in losungen. Z. phys. Chem., 57(A): 387-470.

Ho, Y.S., Mckay, G. 1999. Psuedo-second order model for sorption processes. Process Biochemistry, 34(5): 451-465.

Idris, S., Iyaka, Y.A., Dauda, B.E.N., Ndamitso, M.M., Umar, M.T. 2012. Kinetics study of utilizing ground nut shell as an adsorbent in removing Chromium and Nickel from Dye effluent. American Chemical Sci. J., 2(1): 12-24.

Igwe. J.C., Abia, A.A., Ibeh, C.A. 2008. Adsorption kinetics and intraparticulate diffusivities of $\mathrm{Hg}$, As and $\mathrm{Pb}$ ions unmodified and Thiolated coconut fibers. Int. J. Environ. Sci. Technol., 5(1): 83-92.

Jassim, S.A., Al-Zubaidy, R.Z., Habib, H.R. 2014. Producing ceramic water purifiers made of Iraqi Betonite Type (Bp11). Baghdad Science J., 11(2): 730-741.

Kamel, M.M., Ibrahm, M.A., Ismael, A.M., El-Motaleeb, M.A. 2004. Adsorption of some heavy metal ions form aqueous solutions by using Kaolinite Clay. Ass. Univ. Bull. Environ. Res., 7(1): 101-110.

Kan, J., Sun, T.H., Sun, L.N., Hai-bo, L. 2006. Adsorption characteristics of copper, lead, zinc and cadmium ions by tourmaline. J. Environ. Sci., 18(6): 1221-1225.

Kot, A., Namiesnik, J. 2000. The role of speciation in analytical chemistry. Trends of Analytical Chem., 19: 69-79.

Kotash, J., Stasicka, Z. 2000. Chromium occurrence in the environment and methods of its speciation. Environ. Pollution, 107: 263-283.

Kurniawan, T.A., Chan, G.Y.S., Lo, W.H., Babel, S. 2005. Comparisons of lowcost adsorbents For treating 
wastewaters laden with heavy metals. Sci. Total Environ., 366(2-3): 409-426. Lagergren, S. 1898. About the theory of so called adsorption of soluble substances. J. Kungliga Sveska Vetenskapsa kademiens Handlmgar. 24: 1-39.

Langmuir, I. 1918. The sorption of gases on plane surfaces of glass, mica and platinum. J. American Chem. Soc., 40: 1361-1403.

Limousin, G., Guadet, J., Charlet, L., Szenknect, S., Barthes, V., Krimissa, M. 2007. Sorption isotherms: A review on physical bases, modelling and measurement. Appl. Geochem., 22: 249-275.

Lugo-Lugo, V., Barrera-Diaz, C., Bilyea, B., Balderas-Halderas-Hernendez Z., P., Ureza-Nunez, F., Sanchez-Mendieta, V. 2010. $\mathrm{Cr}(\mathrm{VI})$ reduction in wastewater using bimetallic galvanic reactor. J. Hazardous Matter, 176: 418-425.

Mungasavali, DeepaPrabhu, Viraghavan, Thiruvenkatachari, Yee-Chung, J. 2007. Biosorption of Chromium from aqueous solutions by pretreated Aspergillus Niger: Batch and column studies. Colloids and surfaces A: Physiological Engineering Aspects, 301(1-3): 214-223.

Nwuche, C.O., Ugoji, E.O. 2008. Effects of heavy metal pollution on the microbial activity. Int. J. Environ. Sci. Technol., 5(3): 409-414.

O' Connell, D.W., Birkinshaw, C., O' Dwyer, T.F. 2008. Heavy metal adsorbents prepared from the modification of cellulose: A review. Bioresource Technol., 99: 6709-6724.

O’Shannessy, D.J., Winzor, D.J. 1996. Interpretation of deviation of Pseudofirst order kinetic behaviour in the characterisation of ligand binding by bio-sorbent technology. Analytical
Biochemistry, 236(2): 275-285.

Onundi, Y.B., Al-Mamun, A., Al-Khatib, M.F., Ahmed, Y.M. 2010. Adsorption of Copper, Nickel and Lead ions from synthetic semiconductors industrial wastewater by palm shell activated carbon. Int. J. Environ. Sci. Tech., 7(4): 751-758.

Ossman, M.E., Mansour, M.S. 2013. Removal of $\mathrm{Cd}(\mathrm{II})$ ions from wastewater by adsorption onto treated old newspaper: kinetic modeling and isotherm studies. Int. J. Industrial Chem., 4(12): 1-7.

Pagnanelli, Francesco, Meinelli, Sara Veglio, Francesco, Toro, Luigi. 2003. Heavy metals removal by Olive Pomace: biosorbent characterization and equilibrium modelling. Chemical Engi. Sci., 58(20): 4709-4717.

Parineeta, P., Shubhangi, N. 2013. Adsorption of chromium from industrial waste water by using Neem leaves as a low cost adsorbent. Int. J. Chem. Phy. Sci., 2: 149-158.

Rao, R.A.K., Ikram, S. 2011. Sorption studies of $\mathrm{Cu}$ (II) on gooseberry fruit (Emblica offinalis) and its removal from electroplating wastewater. Desalination, 277: 390-398.

Rao, R.A.K., Khan, M.A. 2007. Removal and recovery of $\mathrm{Cu}(\mathrm{II}), \mathrm{Cd}(\mathrm{II})$ and $\mathrm{Pb}$ (II) ions from single and multimetal system by batch and column operation on neem oil cake (NOC). Sep. Purif. Technol., 57: 394-402.

Rao, R.A.K., Khatoon, A., Ashfaq, A. 2014. Application of Terminalia Arjuna as potential adsorbent for the removal of $\mathrm{Pb}$ (II) from aqueous solution: Thermodynamics, Kinetics and design. Desalination and Water Treatment, 118.

Sdiri, A.T., Higashi, T., Jamoussi, F. 2014. Adsorption of copper and zinc onto natural clay in single and binary 
systems. Int. J. Environmental Sci.

Technol., 11: 1081-1092.

Shanker, A.K., Cerventes, C., Loza-Tavera, H., Avudainayagam, S. 2005. Chromium Toxicity in plants. Environ. Int., 31: 739-753.

Shrivastava, N.K., Majumbar, C.B. 2008. Novel Bio-filtration methods for the treatment of heavy metals from industrial waste water. J. Hazardous Mater., 151(1): 1-8.

Sudha, R., Kalpana, K., Rajachandrasekar, T., Arivoli, S. 2007.Comparative Study on the Adsorption Kinetics and Thermodynamics of Metal Ions onto Acid Activated Low Cost Pandanus Carbon. Environmental J. Chemistry, 4(2): 238-254.

Wan Ngah, S.W., Hanafiah, M.A.K.M. 2008. Removal of heavy metal ions from wastewater by chemically modified plant wastes as adsorbent: A review. Bioresource Technology, 99: 3935-3948.

Wang, R., Li, Q., Xie, D., Xiao, H., Lu, H. 2013. Synthesis of $\mathrm{NiO}$ using pine as template and adsorption performance for $\mathrm{Pb}(\mathrm{II})$ from aqueous solution. Appl. Surface Sci., 279: 129-136.

Wanida, C., Rachnarin, N. 2015. Heavy Metal Removal from Aqueous Solutions by Chitosan Coated Ceramic Membrane. International Conference on Informatics, Environment, Energy and Application, 82(7): 36-41.

Weber, W.J. 1967. Principal and Application of Water Chemistry, edited by Faust, S.D., and Hunter J.V., Wiley, New York. Pp 643.

\section{How to cite this article:}

Shamim Ahmad, Anwer Ali and Ahmad Ashfaq. 2016. Removal of Cr (VI) from Aqueous Metal Solution using Roasted China Clay. Int.J.Curr.Microbiol.App.Sci. 5(5): 171-185. doi: http://dx.doi.org/10.20546/ijcmas.2016.505.019 